PENELITIAN

\title{
Perbandingan Efektivitas Patient-Controlled Analgesia (PCA) Fentanil, PCA Morfin dan Tramadol Intravena Sebagai Analgetik Pasca Operasi Modified Radical Mastectomy (MRM)
}

\section{Effectivity Comparison of Intravenous Patient-Controlled Analgesia (PCA) Fentanyl, PCA Morphine and Tramadol as Post-Operative Analgetic After Modified Radical Mastectomy (MRM)}

\author{
Arie Faishal Madjan ${ }^{{ }^{*}}$, Widya Istanto Nurcahyo* \\ *Bagian Anestesiologi dan Terapi Intensif, Fakultas Kedokteran, Universitas Diponegoro/ RSUP Dr. Kariadi Semarang \\ ${ }^{\triangle}$ Corespondence/Korespondensi : ariefaishal@gmail.com
}

\section{ABSTRACT}

Background: Modified Radical Mastectomy often accompanied by moderate to severe post-operative pain. Some patients who received intermitten analgesic combination of tramadol and ketorolac still complaining of pain. PCA is a new method of analgesic administration. The use of PCA fentanyl and PCA morphine is expected to be more effective for post-operative pain management patient with MRM.

The aimof study: This study aims to determine the effectivity, side effects and patient satisfaction level between intravenous PCA fentanyl, PCA morphine and tramadol as ananalgesic for post-operative MRM.

Methods: Design of this study was double blind randomized control trial of 36 patients who were scheduled to undergo MRM fulfilled this study criteria. After general anesthesia, the patients were divided into 3 groups of post-operative analgesic treatment: (1) PCA fentanyl group with fentanyl loading dose $50 \mathrm{mcg}$, demand dose $20 \mathrm{mcg}, 10 \mathrm{~min}$ interval lockout, $70 \mathrm{mcg} / \mathrm{hour}$ dose limit, infusion background $30 \mathrm{mcg} / \mathrm{hour;}$ (2) PCA group morphine with morphine loading dose $4 \mathrm{mg}$, demand dose $1 \mathrm{mg}$, 10 minute interval lockout, $6 \mathrm{mg} / \mathrm{hour}$ limit dose, no background infusion; 3) tramadol group who received intravenous tramadol $100 \mathrm{mg} / 8$ hours. Periodic assessment of NRS score, RASS score, vital signs, side effects and patient satisfaction levels during first 24 hourspost-operative. Data analyzed with Shapiro-Wilk followed by Kruskal-Wallisor One Way ANOVA, were considered significant if $p<0.05$.

Result: PCA fentanyl is the most effective, followed by PCA morphine then tramadol. $P C A$ fentanyl and PCA morphine RASS score are lower than tramadol $(\mathrm{p}=0,000)$. Drugs side effects are nausea,vomiting and dizziness which not statistically significant. PCA fentanyl provides the highest patient satisfaction level, while there is no significant

Volume X, Nomor 2, Tahun 2018

Terakreditasi DIKTI dengan masa berlaku 3 Juli 2014 - 2 Juli 2019

Dasar SK Menteri Pendidikan dan Kebudayaan RI Nomor 212/P/2014 
differences between PCA morphine and tramadol $(\mathrm{p}=0,009)$. Blood pressure, respiratory rate and pulse rate PCA fentanyl and PCA morphine is significantly lower than tramadol group.

Conclusion: PCA fentanyl is the most effective compare to PCA morphine and tramadol. PCA fentanyl provides the highest satisfaction level? Drugs side effects were not significant in all group treatment.

Keyword: Effectivity; fentanyl; morfin; MRM; PCA; tramadol

\section{ABSTRAK}

Latar Belakang: Operasi Modified Radical Mastectomy menimbulkan nyeri derajat sedang hingga berat pasca operasi. Sebagian pasien yang mendapat kombinasi anagetik tramadol dan ketorolak secara berkala, masih mengeluh nyeri. PCA merupakan metode baru pemberian analgetik. Penggunaan PCA fentanil dan PCA morfin diharapkan dapat lebih efektif dalam mengatasi nyeri pasca operasi MRM.

Tujuan: Penelitian ini bertujuan untuk mengetahui perbandingan efektivitas, efek samping dan tingkat kepuasan pasien antara penggunaan PCA fentanil, PCA morfin dan tramadol intravena sebagai analgetik pasca operasi MRM.

Metode: Dilakukan uji klinis tersamar ganda terhadap 36 pasien rencana operasi MRM yang memenuhi kriteria penelitian. Setelah dilakukan anestesi umum, pasien dibagi dalam 3 kelompok perlakuan pemberian analgetik pasca operasi: (1) kelompok PCA fentanil dengan fentanil loading dose $50 \mathrm{mcg}$, demand dose $20 \mathrm{mcg}$, lockout interval 10 menit, limitdose $70 \mathrm{mcg} / \mathrm{jam}$, background infusion $30 \mathrm{mcg} / \mathrm{jam}$; (2) kelompok PCA morfin dengan morfin loading dose $4 \mathrm{mg}$, demand dose $1 \mathrm{mg}$, lockout interval 10 menit, limit dose $6 \mathrm{mg} / \mathrm{jam}$, tanpa background infusion; (3)kelompok tramadol yang mendapat tramadol intravena $100 \mathrm{mg} / 8 j a m$. Dilakukan penilaian berkala skor NRS, RASS, tanda vital, efek samping dan tingkat kepuasan pasien selama 24 jam pasca operasi. Data dianalisa dengan Shapiro-Wilk dilanjutkan Kruskal-Wallis atau One way ANOVA, dianggap bermakna bila $p<0,05$.

Hasil: Efektivitas terbaik pada PCA fentanil, diikuti PCA morfin lalu tramadol. Skor RASS PCA fentanil dan PCA morfin lebih rendah dari tramadol $(p=0,000)$. Terdapat efek samping mual, muntah dan dizziness yang secara statistik tidak berbeda bermakna. Tingkat kepuasan pasien tertinggi pada kelompok PCA fentanil, sedangkan antara kelompok PCA morfin dan tramadol tidak berbeda bermakna $(p=0,009)$.

Simpulan: PCA fentanil dan PCA morfin lebih efektif dibandingkan tramadol. PCA fentanil memberikan tingkat kepuasan pasien yang lebih tinggi dibanding PCA morfin dan tramadol. Terdapat efek samping mual, muntah dan dizziness namun secara statistik tidak berbeda bermakna.

Kata Kunci: Efektifitas; efeksamping; fentanyl; morfin; MRM; PCA; Tramadol 


\section{PENDAHULUAN}

Nyeri merupakan pengalaman sensorik dan emosional yang tidak menyenangkan akibat kerusakan jaringan baik aktual maupun potensial atau yang digambarkan dalam bentuk kerusakan tersebut. ${ }^{1}$ Nyeri dapat menyebabkan perubahan fisiologis, gangguan emosi, gangguan tidur, depresi dan kecemasan yang mengganggu kualitas hidup seseorang, sehingga perlu dilakukan pengelolaan nyeri yang baik. ${ }^{2,3}$ Operasi Modified Radical Mastectomy (MRM) diketahui dapat menyebabkan rasa sakit derajat sedang hingga berat, terutama saat bergerak dan dapat menjadi nyeri kronik dengan gejala yang dikenal dengan Post Mastectomy Pain Syndrome (PMPS). ${ }^{4,5}$

PCA merupakan metode baru pemberian analgesia yang disesuaikan kebutuhan pasien dan dikendalikan sendiri oleh pasien dengan atau tanpa disertai infuse kontinyu. ${ }^{6,7}$ Adanya perbedaan Minimum Effective Analgesic Concentration (MEAC) pada tiap individu, merupakan hal yang mendasari penggunaan PCA. Melalui PCA, kadar opioid plasma dapat dipertahan kan dengan konstan setelah MEAC tercapai, sesuai dosis yang telah diatur. ${ }^{8-10}$ Dengan menggunakan PCA, dosis obat yang digunakan lebih individualistik, sehingga efektifitas analgesia lebih baik, meminimalkan efek samping dan memberi tingkat kepuasan pasien yang lebih tinggi dibandingkan pemberian analgesia secara konvensional. ${ }^{7,10}$

Morfin merupakan analgetik agonis reseptor opioid $\mu$ dan $\kappa$ pada sistem saraf pusat yang menimbulkan efek analgesia, sedasi, euforia dan depresi pernapasan. ${ }^{14,15}$ Morfin memiliki metabolit aktif, morphine-6-glukuronida yang eliminasinya bergantung terutama pada ekskresi ginjal.

Fentanil merupakan anagetik opioid turunan phenylpiperidine yang 80-100 kali lebih poten dari morfin dan lebih lipofilik sehingga mempunyai onset yang lebih cepat dari morfin. Penggunaan PCA fentanil merupakan alternative bagi pasien dengan intoleransi morfin dan pasien dengan gagal ginjal. ${ }^{6,7}$

Tramadol memberikan efek analgetik melalui aktivasi reseptor $\mu$ opioid dan meningkatkan level sinaptik neuronal sentral dari serotonin dan noradrenalin. Efek analgetiknya 10-15 kali lebih lemah dibandingkan dengan morfin, namun efeksampingnya juga lebih sedikit. Pemberian berulang pada dosis terapi tidak menyebabkan ketergantungan dan jarang terjadi depresi nafas., ${ }^{2,12}$

\section{METODE}

Penelitian dilaksanakan pada bulan September-November 2017 pada pasien yang menjalani operasi MRM elektif di RSUP Dr. Kariadi Semarang setelah mendapatkan etichal clearance dari Komisi Etik RSUP Dr. Kariadi. Sebanyak 36 pasien yang menjadi sampel penelitian dikelompokkan menjadi 3 kelompok perlakuan (12 pasien tiap kelompok): (1) Kelompok 1 mendapat analgetik pasca operasi PCA fentanil selama 24 jam; (2) Kelompok 2 mendapat PCA morfin; (3) Kelompok 3 mendapat tramadol $100 \mathrm{mg}$ intravena tiap 8 jam selama 24 jam. Kriteria inklusi: (1) Dewasa usia 18-60 tahun; (2) Menjalani operasi MRM elektif di RSUP Dr. Kariadi Semarang; (3) Body Mass Index BMI 18,5 - $30 \mathrm{~kg} / \mathrm{m}^{2}$; (4) status fisik 
ASA I-II; (5) Tidak sedang hamil atau menyusui; (6) Tidak asma atau gangguan napas berat; (7) Tidak menderita ulkus peptikum; (8) Tidak memiliki gangguan fungsi ginjal dengan serum kreatinin $>2$ $\mathrm{mg} / \mathrm{dl}$; (9) Tidak alergi opioid, NSAID atau agen anestesi lain yang digunakan dalam penelitian; (10) Tidak sedang menggunakan opioid jangka panjang, dan mampu menggunakan Numerical Rating Scales (NRS). Kriteria eksklusi: (1) Keterbatasan komunikasi karena gangguan kesadaran atau kognitif lain; (2) pasien dengan tindakan operasi ulang; (3) Syok atau komplikasi mayor anestesi atau bedah lainnya selama operasi. Selama penelitian tidak ada sampel penelitian yang di-drop out.

Pasien diberikan midazolam $3 \mathrm{mg}$ intravena sebelum induksi. Induksi dengan propofol (2-2,5 $\mathrm{mg} / \mathrm{kgBB})$, rocuronium $(0,5 \mathrm{mg} / \mathrm{kgBB})$, fentanil (2 $\mathrm{mcg} / \mathrm{kgBB})$ dan ketorolak $30 \mathrm{mg}$ intravena. Setelah tertidur, dilakukan intubasi endotrakeal. Pemeliharaan anestesi dengan oksigen dan $\mathrm{N}_{2} \mathrm{O}$ 50:50 dan sevofluran dengan 2 vol\%. 30 menit sebelum operasi selesai, diberikan injeksi ondansentron $4 \mathrm{mg}$ intravena. Analgetik pasca operasi kelompok perlakuan 1 menggunakan PCA fentanil intravena dengan loading dose $50 \mathrm{mcg}$, demand dose $20 \mathrm{mcg}$, lockout interval 10 menit, limit dose $70 \mathrm{mcg} / \mathrm{jam}$, background infusion $30 \mathrm{mcg} / \mathrm{jam}$ dimulai pada saat pasien tiba di ruang pulih sadar (jam ke0 ); kelompok perlakuan 2 menggunakan PCA morfin intravena loading dose 4 $\mathrm{mg}$, demand dose $1 \mathrm{mg}$, lockout interval
10 menit, limit dose $6 \mathrm{mg} / \mathrm{jam}$, background infusion tidak diberikan dimulai pada saat pasien tiba di ruang pulih sadar (jam ke-0); kelompok perlakuan 3 menggunakan tramadol 100 mg intravena tiap 8 jam, mulai diberikan 30 menit sebelum ekstubasi. Seluruh kelompok mendapat injeksi ketorolak 30 mg intravena setiap 8 jam, dimulai 8 jam setelah induksi. Skor NRS, tanda vital, efek samping dinilai pada jam ke-0, 1, 6, 12 dan 24 pasca operasi.

Bila terjadi hipotensi (tekanan darah $<90 / 60$ ), obat dikurangi dosisnya dan injeksi efedrin $10 \mathrm{mg}$ i.v. Bila mual muntah, diberikan anti emetik metokloperamid $10 \mathrm{mg}$ i.v bila perlu ditambah ondansentron $4 \mathrm{mg}$ i.v setiap 8 jam. Bila terjadi bradikardi, diberikan injeksi sulfasatropin 0,5 mgi.v dan pengurangan dosis obat opioid. Bila terjadi penurunan kesadaran hingga skor RASS lebih rendah dari -3 dan depresi napas ( $R R<8 \mathrm{x} /$ menit) maka obat opioid dihentikan, dan diberikan nalokson i.v Analgetik setelah 24 jam pasca operasi menggunakan tramadol $50 \mathrm{mg}$ dan ketorolak $30 \mathrm{mg}$ intravena tiap 8 jam selama 2 hari.

$\begin{array}{rlrr}\text { Data } & \text { yang } & \text { dihasilkan akan } \\ \text { dilakukan } & \text { uji } & \text { normalitas } & \text { data }\end{array}$ menggunakan Uji Shapiro Wilks, bila data terdistribusi normal akan dilakukan uji One Way ANOVA dilanjutkan dengan uji post hoc Bonferroni. Bila data tidak terdistribusi normal akan dilakukan Uji Kruskal Wallis dan uji post hoc Mann Whitney $U$. 
HASIL

Tabel 1. Karakteristik Subjek Penelitian

\begin{tabular}{|c|c|c|c|c|}
\hline Variabel & Fentanil & Morfin & Tramadol & $\mathrm{p}$ \\
\hline Umur (tahun) & $48,17 \pm 4,40$ & $49,25 \pm 7,56$ & $49,5 \pm 10,44$ & $0,487^{7}$ \\
\hline Berat badan $(\mathrm{kg})$ & $54,08 \pm 3,65$ & $54,42 \pm 5,10$ & $54,83 \pm 4,76$ & $0,922^{\mathfrak{f}}$ \\
\hline Tinggi badan $(\mathrm{cm})$ & $158,33 \pm 4,33$ & $155,42 \pm 4,98$ & $156,58 \pm 4,81$ & $0,325^{\mathfrak{f}}$ \\
\hline BMI $\left(\mathrm{kg} / \mathrm{m}^{2}\right)$ & $21,6 \pm 1,74$ & $22,54 \pm 2,04$ & $22,40 \pm 2,24$ & $0,480^{\mathfrak{f}}$ \\
\hline
\end{tabular}

Keterangan : Data ditampilkan dengan nilai rerata $\pm \mathrm{SD} ;{ }^{*}$ Kruskal Wallis; ${ }^{£}$ one way ANOVA

Berdasarkan data pada tabel 1, maka secara umum karakteristik subjek penelitian pada penelitian ini dari segi umur, berat badan, tinggi badan dan BMI tidak berbeda secara bermakna, sehingga dapat dilakukan uji statistic tahap selanjutnya.

Tabel 2. NRS Saat Diam dan Bergerak

\begin{tabular}{llllllll}
\hline \multirow{2}{*}{ Variabel } & \multicolumn{2}{c}{ Fentanil } & \multicolumn{2}{c}{ Morfin } & \multicolumn{2}{c}{ Tramadol } & $p$ \\
\cline { 2 - 7 } & \multicolumn{1}{c}{ Mean \pm SD } & Median & Mean \pm SD & Median & Mean \pm SD & Median \\
\hline NRS D 0 & $0,00 \pm 0,00$ & $0(0)$ & $0 \pm 0$ & $0(0)$ & $0,25 \pm 0,866$ & $0(0-3)$ & $0,368^{*}$ \\
NRS D 1 & $0,00 \pm 0,00$ & $0(0)$ & $0 \pm 0$ & $0(0)$ & $0,17 \pm 0,577$ & $0(0-2)$ & $0,368^{*}$ \\
NRS D 6 & $0,42 \pm 0,996$ & $0(0-3)$ & $0,58 \pm 0,996$ & $0(0-3)$ & $3,0 \pm 0,00$ & $3(3)$ & $0,000^{* *}$ \\
NRS D 12 & $0,42 \pm 0,996$ & $0(0-3)$ & $1,67 \pm 0,985$ & $1,5(0-3)$ & $3,0 \pm 0,00$ & $3(3)$ & $0,000^{* *}$ \\
NRS D 24 & $0,58 \pm 0,793$ & $0(0-2)$ & $1,50 \pm 0,522$ & $1,5(1-2)$ & $2,25 \pm 0,452$ & $2(2-3)$ & $0,000^{* *}$ \\
& & & & & & & \\
NRS B 0 & $0,00 \pm 0,00$ & $0(0)$ & $0,00 \pm 0,00$ & $0(0)$ & $0,42 \pm 1,443$ & $0(0-5)$ & $0,368^{*}$ \\
NRS B 1 & $0,42 \pm 0,996$ & $0(0-3)$ & $0,58 \pm 1,084$ & $0(0-3)$ & $1,17 \pm 1,801$ & $0(0-5)$ & $0,504^{*}$ \\
NRS B 6 & $2,83 \pm 1,030$ & $2,5(2-5)$ & $3,25 \pm 0,622$ & $3(3-5)$ & $5,17 \pm 0,389$ & $5(5-6)$ & $0,000^{* *}$ \\
NRS B 12 & $3,25 \pm 0,622$ & $3(3-5)$ & $3,92 \pm 0,900$ & $4(3-5)$ & $5,67 \pm 0,651$ & $6(5-7)$ & $0,000^{* *}$ \\
NRS B 24 & $3,08 \pm 0,289$ & $3(3-4)$ & $3,08 \pm 0,289$ & $3(3-4)$ & $4,92 \pm 0,669$ & $5(4-6)$ & $0,000^{* *}$
\end{tabular}

Keterangan : NRS D (NRS saat diam); NRS B (NRS saat bergerak); ${ }^{\ddagger}$ Kruskal Wallis; * signifikan.

Tabel 2 menampilkan hasil uji Shapiro-Wilk NRS saat diam pada jam ke-0, 1, 6, 12 dan 24 (NRS D 0, 1, 6, 12, 24) pada semua kelompok didapatkan hasil tidak normal sehingga dilakukan uji Kruskal-Wallis. NRS D 0 dan NRS D 1 antar semua kelompok dengan uji Kruskal-Wallis secara statistik tidak berbeda bermakna $(\mathrm{p}=0,368)$. NRS D 6, 12 dan 24 berbeda bermakna $(p=0,000)$ kemudian dilanjutkan uji Mann-Whitney. Uji normalitas NRS saat bergerak pada jam ke-0, 1, 6, 12 dan 24 (NRS B 0, 1, 6, $12,24)$ pada semua kelompok didapatkan hasil tidak normal sehingga dilakukan uji Kruskal-Wallis. NRS B 0 dan NRS B 1 dengan uji Kruskal-Wallis secara statistik tidak berbeda bermakna. NRS D 6, 12 dan 24 berbeda bermakna kemudian dilanjutkan uji Mann-Whitney. 
Tabel 3. Perbandingan NRS Saat Diam pada Jam ke-6, 12 dan 24

\begin{tabular}{llll}
\hline & \multicolumn{1}{c}{ Kelompok } & Mean Rank & $\mathrm{p}$ \\
\hline NRS D 6 & Fentanil & 11,67 & 0,447 \\
& Morfin & 13,33 & \\
NRS D 12 & Fentanil & 8,42 & $0,003^{*}$ \\
& Morfin & 16,58 & \\
NRS D 24 & Fentanil & 8,75 & $0,006^{*}$ \\
& Morfin & 16,25 & \\
NRS D 6 & Fentanil & 7,00 & $0,000^{*}$ \\
& Tramadol & 18,00 & \\
NRS D 12 & Fentanil & 7,00 & $0,000^{*}$ \\
& Tramadol & 18,00 & \\
NRS D 24 & Fentanil & 7,25 & $0,000^{*}$ \\
& Tramadol & 17,75 & \\
NRS D 6 & Morfine & 7,00 & $0,000^{*}$ \\
& Tramadol & 18,00 & \\
NRS D 12 & Morfin & 8,00 & $0,000^{*}$ \\
& Tramadol & 17,00 & \\
NRS D 24 & Morfin & 8,75 & $0,003^{*}$ \\
& Tramadol & 16,25 & \\
\hline
\end{tabular}

Keterangan : * Signifikan

Tabel 3 menampilkan hasil uji Mann-Whitney untuk perbandingan NRS saat diam antara kelompok FentanilMorfin pada jam ke-6 tidak berbeda bermakna $(p=0,447)$, sedangkan pada jam ke $12(p=0,003)$ dan $24 \quad(p=0,006)$ berbeda bermakna, dengan skor NRS kelompok fentanil lebih rendah dari pada kelompok morfin. NRS saat diam antara kelompok Fentanil-Tramadol pada jam ke
$-6, \quad 12$ dan 24 berbeda bermakna $(\mathrm{p}=0,000)$, dengan skor NRS kelompok fentanil lebih rendah daripada kelompok tramadol. NRS saat diam antara kelompok Morfin-Tramadol pada jam ke$6(p=0,000), 12 \quad(p=0,000)$ dan 24 $(p=0,003)$ berbeda bermakna, dengan skor NRS kelompok morfin lebih rendah daripada kelompok tramadol.

Tabel 4. Perbandingan NRS Saat Bergerak pada Jam ke-6, 12 dan 24

\begin{tabular}{lllll}
\hline & \multicolumn{1}{c}{ Kelompok } & \multicolumn{1}{c}{ MeanRank } & p \\
\hline NRS B 6 & Fentanil & 10,46 & 0,119 & \\
& Morfin & 14,54 & $0,041^{*}$ & \\
NRS B 12 & Fentanil & 9,96 & & \\
& Morfin & 15,04 & 0,546 & \\
NRS B 24 & Fentanil & 12,00 & & \\
& Morfin & 13,00 & $0,000^{*}$ & \\
NRS B 6 & Fentanil & 6,92 & & \\
& Tramadol & 18,08 & $0,000^{*}$ & \\
NRS B 12 & Fentanil & 6,71 & & \\
& Tramadol & 18,29 & $0,000^{*}$ &
\end{tabular}




\begin{tabular}{llll} 
& & \\
NRS B 6 & Mornal Anestesiologi Indonesia & 6,92 & $0,000^{*}$ \\
& Tramadol & 18,08 & $0,000^{*}$ \\
NRS B 12 & Morfin & 7,33 & $0,000^{*}$ \\
& Tramadol & 17,67 & \\
\hline
\end{tabular}

Keterangan : ${ }^{*}$ Signifikan

Tabel 4 menampilkan hasil uji Mann-Whitney untuk perbandingan NRS saat bergerak antara kelompok FentanilMorfin pada jam ke-6 tidak berbeda bermakna $(p=0,119)$, sedangkan pada jam ke $12(p=0,041)$ dan $24 \quad(p=0,546)$ berbeda bermakna, dengan skor NRS kelompok fentanil lebih rendah daripada kelompok morfin. NRS saat bergerak antara kelompok Fentanil-Tramadol pada jam ke-6, 12 dan 24 berbeda bermakna $(\mathrm{p}=0,000)$, dengan skor NRS kelompok fentanil lebih rendah daripada kelompok tramadol. NRS saat bergerak antara kelompok Morfin-Tramadol pada jam ke6, 12 dan 24 berbeda bermakna $(0,000)$, dengan skor NRS kelompok morfin lebih rendah daripada kelompok tramadol.

Tabel 5. Skor Richmond Agitation Sedation Scales (RASS)

\begin{tabular}{clllllll}
\hline \multirow{2}{*}{$\begin{array}{c}\text { Skor } \\
\text { RASS }\end{array}$} & \multicolumn{2}{c}{ Fentanil } & \multicolumn{2}{c}{ Morfin } & \multicolumn{2}{c}{ Tramadol } & $\mathrm{p}$ \\
\cline { 2 - 7 } & \multicolumn{2}{c}{ Mean \pm SD } & Median & Mean \pm SD & Median & Mean \pm SD & Median \\
\hline Jam ke-0 & $-1,58 \pm 0,515$ & $-2(-2--1)$ & $-1,58 \pm 0,515$ & $-2(-2--1)$ & $-0,5 \pm 0,674$ & $-1(-1-1)$ & $0,000^{\ddagger *}$ \\
Jam ke-1 & $-0,17 \pm 0,389$ & $0(-1-0)$ & $-0,17 \pm 0,389$ & $0(-1-0)$ & $0 \pm 0,426$ & $-1(-1-1)$ & $0,522^{\ddagger}$ \\
Jam ke-6 & $-0,25 \pm 0,452$ & $0(-1-0)$ & $-0,25 \pm 0,452$ & $0(-1-0)$ & $0 \pm 0,000$ & $0(0)$ & $0,174^{\ddagger}$ \\
Jam ke-12 & $0,00 \pm 0,000$ & $0(0)$ & $0,00 \pm 0,000$ & $0(0)$ & $0 \pm 0,000$ & $0(0)$ & $1,000^{\ddagger}$ \\
Jam ke-24 & $0,00 \pm 0,000$ & $0(0)$ & $0,00 \pm 0,000$ & $0(0)$ & $0 \pm 0,000$ & $0(0)$ & $1,000^{\ddagger}$ \\
& & & & & & & \\
\hline
\end{tabular}

Keterangan: ${ }^{*}$ Kruskal Wallis, * signifikan

Tabel 5 menampilkan skor RASS pada jam ke-0, 1, 6, 12 dan 24 (RASS 0, 1, 6, 12 dan 24). Uji ShapiroWilk pada RASS 0, 1 dan 6 didapatkan hasil tidak normal $(\mathrm{p}<0,05)$ sehingga dilakukan uji Kruskal-Wallis. RASS 0 dengan uji Kruskal-Wallis secara statistik berbeda bermakna $(p=0,000)$ kemudian dilanjutkan uji Mann-Whitney. RASS 1 $(\mathrm{p}=0,522), 6(\mathrm{p}=0,174), 12(\mathrm{p}=1,000)$ dan $24(\mathrm{p}=1,000)$ dengan uji Kruskal-Wallis secara statistik tidak berbeda bermakna.

Tabel 6. Perbandingan Skor RASS pada jam ke-0

\begin{tabular}{llll}
\hline \multirow{2}{*}{ RASS 0 } & \multicolumn{1}{c}{ Kelompok } & \multicolumn{1}{c}{ MeanRank } & $\mathrm{p}$ \\
& Fentanil & 12,50 & 1,000 \\
RASS 0 & Morfin & 12,50 & \\
& Fentanil & 7,96 & $0,001^{*}$ \\
RASS 0 & Tramadol & 17,04 & \\
& Morfin & 7,96 & $0,001^{*}$ \\
& Tramadol & 17,04 & \\
\hline
\end{tabular}

Keterangan : * Signifikan 
Tabel 6 menampilkan hasil uji Mann-Whitney untuk perbandingan RASS jam ke-0 antara kelompok FentanilMorfin tidak berbeda bermakna $(p=1,000)$, sedangkan antara kelompok Fentanil-Tramadol berbeda bermakna $(p=0,001)$, dengan skor RASS 0 kelompok fentanil lebih rendah daripada kelompok tramadol. RASS 0 antara kelompok Morfin-Tramadol berbeda bermakna $(p=0,001)$, dengan skor RASS 0 kelompok morfin lebih rendah daripada kelompok tramadol.

Tabel 7. Resume Jawaban Kuesioner Tingkat Kepuasan Pasien Tiap Kelompok

\begin{tabular}{|c|c|c|c|c|}
\hline No & Pertanyaan & Tramadol & Fentanil & Morfin \\
\hline 1 & $\begin{array}{l}\text { Nyeri PALING RINGAN yang anda } \\
\text { rasakan dalam } 24 \text { jam } \\
\text { (0 tidak nyeri, } 10 \text { sangat nyeri) }\end{array}$ & $0,2 \pm 0,58$ & $0,0 \pm 0,0$ & $0,0 \pm 0,0$ \\
\hline 2 & $\begin{array}{l}\text { Nyeri PALING BERAT yang anda } \\
\text { rasakan dalam } 24 \text { jam } \\
\text { ( } 0 \text { tidak nyeri, } 10 \text { sangat nyeri) }\end{array}$ & $5,8 \pm 0,58$ & $3,3 \pm 0,65$ & $4,0 \pm 0,95$ \\
\hline 3 & $\begin{array}{l}\text { Seberapa sering anda mengalami NYERI } \\
\text { BERAT dalam } 24 \text { jam } \\
\text { ( } 0 \text { tidak pernah, } 10 \text { selalu nyeri) }\end{array}$ & $0,0 \pm 0,0$ & $0,0 \pm 0,0$ & $0,0 \pm 0,0$ \\
\hline \multirow[t]{5}{*}{4} & $\begin{array}{l}\text { Seberapa besar rasa nyeri mempengaruhi } \\
\text { anda untuk melakukan aktivitas berikut: } \\
\text { ( } 0 \text { tidak terganggu, } 10 \text { sangat terganggu) }\end{array}$ & & & \\
\hline & $\begin{array}{l}\text { a. Aktivitas di tempat tidur (bangun, } \\
\text { miring kanan kiri) }\end{array}$ & $2,3 \pm 1,37$ & $0,3 \pm 0,78$ & $0,8 \pm 1,27$ \\
\hline & $\begin{array}{l}\text { b. Aktivitas di luar tempat tidur } \\
\text { (berjalan, duduk di kursi, berdiri) }\end{array}$ & $4,2 \pm 1,47$ & $1,2 \pm 1,47$ & $2,3 \pm 2,09$ \\
\hline & c. Mulai tidur & $0,0 \pm 0,0$ & $0,0 \pm 0,0$ & $0,0 \pm 0,0$ \\
\hline & d. Tetap tertidur & $2,3 \pm 2,61$ & $0,0 \pm 0,0$ & $0,0 \pm 0,0$ \\
\hline \multirow[t]{5}{*}{5} & $\begin{array}{l}\text { Nyeri dapat mempengaruhi mood dan } \\
\text { emosi, nyeri yang anda rasakan membuat } \\
\text { anda merasa: } \\
\text { ( } 0 \text { tidak sama sekali, } 10 \text { sangat } \\
\text { terpengaruh) }\end{array}$ & & & \\
\hline & a. Cemas & $0,0 \pm 0,0$ & $0,0 \pm 0,0$ & $0,0 \pm 0,0$ \\
\hline & b. Depresi & $0,0 \pm 0,0$ & $0,0 \pm 0,0$ & $0,0 \pm 0,0$ \\
\hline & c. Takut & $0,0 \pm 0,0$ & $0,0 \pm 0,0$ & $0,0 \pm 0,0$ \\
\hline & d. Putusasa & $0,0 \pm 0,0$ & $0,0 \pm 0,0$ & $0,0 \pm 0,0$ \\
\hline \multirow[t]{5}{*}{6} & $\begin{array}{l}\text { Apakah anda mengalami efek samping } \\
\text { berikut: } \\
\text { ( } 0 \text { tidak sama sekali, } 10 \text { sangat } \\
\text { terpengaruh) }\end{array}$ & & & \\
\hline & a. Mual & $3,8 \pm 3,01$ & $3,6 \pm 2,81$ & $6,3 \pm 2,56$ \\
\hline & b. Mengantuk & $0,0 \pm 0,0$ & $0,0 \pm 0,0$ & $0,6 \pm 2,02$ \\
\hline & c. Gatal & $0,0 \pm 0,0$ & $0,0 \pm 0,0$ & $0,0 \pm 0,0$ \\
\hline & d. Pusing & $0,4 \pm 1,44$ & $0,0 \pm 0,0$ & $0,0 \pm 0,0$ \\
\hline 7 & $\begin{array}{l}\text { Selama } 24 \text { jam ini, seberapa besar nyeri } \\
\text { hilang setelah pemberian obat? } \\
\text { ( } 0 \text { tidak hilang sama sekali, } 10 \text { nyeri } \\
\text { hilang total) }\end{array}$ & $\begin{array}{l}70,83 \pm \\
14,43\end{array}$ & $93,33 \pm 6,51$ & $\begin{array}{l}80,83 \pm \\
10,84\end{array}$ \\
\hline 8 & $\begin{array}{l}\text { Apakah anda diikutsertakan dalam } \\
\text { memilih/menentukan pemberian obat } \\
\text { nyeri? } \\
\text { (0 tidak ikut, } 10 \text { diikutsertakan) }\end{array}$ & $0,0 \pm 0,0$ & $10,0 \pm 0,0$ & $10,0 \pm 0,0$ \\
\hline
\end{tabular}


9 Seberapa puas anda dengan pengelolaan nyeri yang anda dapatkan?

(0 tidak puas, 10 sangat puas)

10 Apakah anda diberikan informasi mengenai pemilihan terapi nyeri? Ya /

Tidak

Jika ya, seberapa membantu informasi tersebut untuk anda?

(0 tidak membantu, 10 sangat membantu)

11 Apakah andamennggunakan terapi selain obat untuk mengghilangkan rasa nyeri? Ya / Tidak

Jika Ya, terapi apa yang anda gunakan? Ya

$$
\text { Tidak }
$$

12 Seberapa sering perawat atau dokter menyuruh anda menggunakan terapi di atas?

$$
\begin{aligned}
& \text { Pernah } \\
& \text { Tidak pernah }
\end{aligned}
$$

$7,08 \pm 1,379$

$8,58 \pm 1,311 \quad 7,08 \pm 0,793$

$6,8 \pm 1,80$

$8,7 \pm 0,78$

$8,4 \pm 0,67$
$4(33,3 \%) \quad 1(8,3 \%) \quad 0(0 \%)$

$8(66,7 \%) \quad 11(91,7 \%) \quad 12(100 \%)$

$0(0 \%)$

$0(0 \%)$

$0(0 \%)$

$12(100 \%)$

\begin{tabular}{|c|c|c|c|c|c|c|}
\hline \multicolumn{2}{|c|}{ Fentanil } & \multicolumn{2}{|c|}{ Morfin } & \multicolumn{2}{|c|}{ Tramadol } & $\mathrm{p}$ \\
\hline Mean $\pm \mathrm{SD}$ & $\begin{array}{l}\text { Median } \\
\text { (range) }\end{array}$ & Mean \pm SD & $\begin{array}{l}\text { Median } \\
\text { (range) }\end{array}$ & Mean \pm SD & $\begin{array}{l}\text { Median } \\
\text { (range) }\end{array}$ & \\
\hline $8,58 \pm 1,311$ & $8,5(6-10)$ & $7,08 \pm 0,793$ & $7(6-8)$ & $7,08 \pm 1,379$ & $7(5-10)$ & $0,009^{\ddagger *}$ \\
\hline
\end{tabular}

Tabel 8. Tingkat Kepuasan Pasien

Keterangan : ${ }^{\ddagger}$ Kruskal Wallis, ${ }^{*}$ Signifikan

Hasil uji Shapiro-Wilk untuk tingkat kepuasan pasien semua kelompok tidak normal dan dilanjutkan KruskalWallis. Uji Kruskal-Wallis menunjukkan perbandingan tingkat kepuasan pasien secara statistik berbeda bermakna $(\mathrm{p}=0,009)$ dan dilanjutkan uji MannWhitney.

Tabel 9. Perbandingan Tingkat Kepuasan Pasien

\begin{tabular}{lcc}
\hline \multicolumn{1}{c}{ Kelompok } & MeanRank & $\mathrm{p}$ \\
\hline Fentanil & 16,42 & $0,005^{*}$ \\
Morfin & 8,58 & \\
Fentanil & 16,00 & $0,013^{*}$ \\
Tramadol & 9,00 & \\
Morfin & 12,00 & 0,716 \\
Tramadol & 13,00 & \\
\hline
\end{tabular}

Keterangan : * Signifikan

Tabel 9 menampilkan hasil uji Mann-Whitney untuk perbandingan tingkat kepuasan pasien antara kelompok Fentanil-Morfin berbeda bermakna $(p=0,005)$ dengan tingkat kepuasan pasien kelompok fentanil lebih tinggi daripada kelompok morfin, sedangkan antara kelompok Fentanil-Tramadol berbeda bermakna $(p=0,013)$, dengan tingkat kepuasan kelompok fentanil lebih 
tinggi daripada kelompok tramadol. Perbandingan tingkat kepuasan antara kelompok Morfin-Tramadol tidak berbeda bermakna $(p=0,716)$. Tingkat kepuasan pasien tertinggi pada kelompok fentanil sedangkan antara kelompok tramadol-morfin tidak berbeda bermakna.

Tabel 10. Jumlah Konsumsi Obat

\begin{tabular}{|c|c|c|c|c|c|c|c|}
\hline \multirow[t]{2}{*}{ Kelompok } & \multirow[t]{2}{*}{$\begin{array}{l}\text { Dosis } \\
\text { bolus }\end{array}$} & \multicolumn{2}{|c|}{$\begin{array}{l}\text { Doses Given } \\
\text { (dose) }\end{array}$} & \multicolumn{2}{|c|}{$\begin{array}{l}\text { DosesAttempted } \\
\text { (dose) }\end{array}$} & \multicolumn{2}{|c|}{ Total dosis yang diberikan } \\
\hline & & mean & median & mean & median & mean & median \\
\hline Fentanil & $50 \mathrm{mcg}$ & 2,33 & $\begin{array}{l}2 \\
(0-6)\end{array}$ & 3,08 & $3(0-9)$ & $817,25 \mathrm{mcg}$ & $\begin{array}{l}811,5 \\
(768-888) \mathrm{mcg}\end{array}$ \\
\hline Morfin & $4 \mathrm{mg}$ & 10,08 & $\begin{array}{l}9,5 \\
(6-16)\end{array}$ & 12,67 & $\begin{array}{l}12,5 \\
(6-20)\end{array}$ & $14,08 \mathrm{mg}$ & $\begin{array}{l}13,5 \\
(10-20) \mathrm{mg}\end{array}$ \\
\hline Tramadol & $100 \mathrm{mg}$ & - & - & - & - & $300 \mathrm{mg}$ & $300(300) \mathrm{mg}$ \\
\hline
\end{tabular}

Tabel 10 menampilkan jumlah konsumsi obat selama 24 jam pertama pasca operasi untuk tiap kelompok. Kelompok fentanil dan morfin menggunakan PCA sedangkan kelompok tramadol dengan injeksi bolus berkala.
Total dosis yang diberikan untuk kelompok fentanil dengan median 811,5 (768-888) mcg, kelompok morfin 13,5 (10-20) mg, dan kelompok tramadol 300 (300) $\mathrm{mg}$.

Tabel 11. Efek Samping dalam 24 jam Pasca Operasi

\begin{tabular}{lcccc}
\hline Efek samping & $\begin{array}{c}\text { Kelompok } \\
\text { Fentanil } \\
(\mathrm{n}=12)\end{array}$ & $\begin{array}{c}\text { Kelompok } \\
\text { Morfin } \\
(\mathrm{n}=12)\end{array}$ & $\begin{array}{c}\text { Kelompok } \\
\text { Tramadol } \\
(\mathrm{n}=12)\end{array}$ & $\mathrm{p}$ \\
\hline Mual & $8(67 \%)$ & $8(67 \%)$ & $7(58 \%)$ & 0,887 \\
Muntah & $1(8 \%)$ & $3(25 \%)$ & $0(0 \%)$ & 0,140 \\
Bradikardi & $0(0 \%)$ & $0(0 \%)$ & $0(0 \%)$ & - \\
Hipotensi & $0(0 \%)$ & $0(0 \%)$ & $0(0 \%)$ & - \\
Depresi napas & $0(0 \%)$ & $0(0 \%)$ & $0(0 \%)$ & - \\
Dizziness & $0(0 \%)$ & $2(17 \%)$ & $1(8 \%)$ & 0,336 \\
Pruritus & $0(0 \%)$ & $0(0 \%)$ & $0(0 \%)$ & - \\
\hline
\end{tabular}

Efek samping yang terjadi selama 24 jam pasca operasi yakni mual, muntah dan dizziness. Mual terjadi pada kelompok fentanil sebanyak 8 pasien, morfin 8 pasien dan tramadol 7 pasien. Muntah terjadi pada kelompok fentanil sebanyak 1 pasien, morfin 3 pasien dan tramadol tidak ada yang muntah, namun secara statistik perbedaan tidak signifikan. Dizziness terjadi pada kelompok morfin 2 pasien dan tramadol 1 pasien, secara statistik perbedaan tidak signifikan. 
Tabel 12. Perbandingan Tekanan Darah Sistolik dan Diastolik Antar Kelompok

\begin{tabular}{|c|c|c|c|c|}
\hline \multirow{2}{*}{$\begin{array}{c}\text { Tekanan } \\
\text { Darah }\end{array}$} & Fentanil & Morfin & \multirow[b]{2}{*}{ Mean $\pm \mathrm{SD}$} & \multirow[t]{2}{*}{$\bar{p}$} \\
\hline & Mean $\pm \mathrm{SD}$ & Mean \pm SD & & \\
\hline Sistolik & & & & \\
\hline Jam ke- 0 & $108,08 \pm 10,388$ & $105,08 \pm 8,447$ & $122,75 \pm 8,454$ & $0,000^{£ *}$ \\
\hline Jam ke-1 & $113,75 \pm 9,697$ & $105,42 \pm 8,565$ & $122,67 \pm 7,655$ & $0,000^{£ *}$ \\
\hline Jam ke-6 & $113,33 \pm 11,547$ & $105,00 \pm 9,045$ & $119,67 \pm 6,972$ & $0,002^{*}$ \\
\hline Jam ke-12 & $111,67 \pm 10,299$ & $108,33 \pm 5,774$ & $122,50 \pm 7,538$ & $0,001^{\ddagger}$ \\
\hline Jam ke-24 & $113,33 \pm 9,847$ & $109,17 \pm 7,930$ & $117,33 \pm 7,499$ & $0,113^{\ddagger}$ \\
\hline Diastolik & & & & \\
\hline Jam ke-0 & $64,42 \pm 3,423$ & $66,25 \pm 5,739$ & $74,50 \pm 9,190$ & $0,001^{\mathfrak{f} *}$ \\
\hline Jam ke-1 & $66,92 \pm 3,397$ & $67,42 \pm 5,107$ & $73,33 \pm 6,880$ & $0,009^{\mathfrak{f} *}$ \\
\hline Jam ke- 6 & $67,50 \pm 6,216$ & $67,50 \pm 7,538$ & $72,67 \pm 9,623$ & $0,210^{\$}$ \\
\hline Jam ke-12 & $69,17 \pm 9,003$ & $69,17 \pm 6,686$ & $72,17 \pm 7,744$ & $0,588^{\ddagger}$ \\
\hline Jam ke-24 & $71,67 \pm 7,177$ & $69,17 \pm 5,149$ & $69,17 \pm 6,686$ & $0,535^{\star}$ \\
\hline
\end{tabular}

Keterangan : ${ }^{\ddagger}$ Kruskal Wallis; ${ }^{\star}$ ANOVA, *Signifikan

Hasil uji normalitas dengan Shapiro-Wilk didapatkan data tekanan darah sistolik (TDS) dan tekanan darah diastolik (TDD) jam ke-0 dan 1berdistribusi normal maka digunakan uji One Way ANOVA, hasilnya berbeda signifikan, maka dilanjutkan uji Post Hoc. Data TDSjam ke-6, 12 dan 24 berdistribusi tidak normal, maka dilanjutkan dengan uji Kruskal-Wallis, dengan hasil TDS jam ke-6 dan 12 berbeda signifikan sehingga dilanjutkan Mann-Whitney, sedangkan TDS jam ke24 tidak berbeda signifikan. TDD jam ke6, 12 dan 24 dengan Shapiro-Wilk tidak normal maka dilanjutkan dengan uji Kruskal-Wallis. Uji Kruskal-Wallis untuk TDD jam ke-6 ( $\mathrm{p}=0,210)$, TDD jam ke$12(\mathrm{p}=0,588)$, TDD jam ke- $24(\mathrm{p}=0,535)$ tidak berbeda signifikan.

Tabel 13. Perbandingan Tekanan Darah Sistolik dan Diastolik pada Jam ke-0 dan 1

\begin{tabular}{llll}
\hline Variabel & \multicolumn{1}{c}{ Kelompok } & \multicolumn{1}{c}{ MeanDifference } & $\mathrm{p}$ \\
\hline TDS 0 & Fentanil-Morfin & 3,000 & 1,000 \\
TDS 0 & Fentanil-Tramadol & $-14,667$ & $0,001^{*}$ \\
TDS 0 & Morfin-Tramadol & $-17,667$ & $0,000^{*}$ \\
TDS 1 & Fentanil-Morfin & 8,333 & 0,074 \\
TDS 1 & Fentanil-Tramadol & $-8,917$ & 0,051 \\
TDS 1 & Morfin-Tramadol & $-17,250$ & $0,000^{*}$ \\
TDD 0 & Fentanil-Morfin & $-1,883$ & 1,000 \\
TDD 0 & Fentanil-Tramadol & $-10,083$ & $0,017^{*}$ \\
TDD 0 & Morfin-Tramadol & $-8,250$ & $0,012^{*}$ \\
TDD 1 & Fentanil-Morfin & $-0,500$ & 1,000 \\
TDD 1 & Fentanil-Tramadol & $-6,417$ & $0,017^{*}$ \\
TDD 1 & Morfin-Tramadol & $-5,917$ & $0,000^{*}$ \\
\hline
\end{tabular}

Keterangan : * Signifikan 
TDS dan TDD jam ke-0 antara kelompok fentanil-tramadol dan morfin-tramadol berbeda bermakna, dengan TDS 0 dan TDD 0 fentanil lebih rendah dari tramadol dan TDS 0 dan TDD 0 morfin lebih rendah dari tramadol. TDS 1 dan TDD 1 antara kelompok morfin-tramadol berbeda bermakna dengan kelompok morfin lebih rendah. TDD 1 kelompok fentanil lebih rendah dari kelompok tramadol.

Tabel 14. Perbandingan Tekanan Darah Sistolik pada Jam ke-6 dan 12

\begin{tabular}{clll}
\hline & Kelompok & MeanRank & P \\
\hline TDS 6 & Fentanil & 14,88 & 0,084 \\
& Morfin & 10,13 & 0,243 \\
TDS 12 & Fentanil & 14,00 & \\
& Morfin & 11,00 & 0,068 \\
& Fentanil & 10,00 & $0,009^{*}$ \\
TDS 6 & Tramadol & 15,00 & $0,001^{*}$ \\
& Fentanil & 8,92 & \\
TDS 12 & Tramadol & 16,08 & $0,000^{*}$ \\
& Morfin & 7,75 & \\
\hline
\end{tabular}

Tabel 14 menampilkan data tekanan darah sistolik antara kelompok fentanil-morfin pada jam ke-6 $(\mathrm{p}=0,084)$ dan $12 \quad(p=0,243)$ tidak berbeda bermakna. Antara kelompok fentaniltramadol pada jam ke-6 $(\mathrm{p}=0,068)$ tidak berbeda bermakna sedangkan pada jam ke-12 $\quad(p=0,009)$ berbeda bermakna dengan tekanan darah kelompok fentanil lebih rendah daripada kelompok tramadol. Antara kelompok morfintramadol pada jam ke-6 $(\mathrm{p}=0,001)$ dan 12 $(\mathrm{p}=0,000)$ berbeda bermakna dengan tekanan darah sistolik kelompok morfin lebih rendah daripada kelompok tramadol.

Tabel 15. Perbandingan Laju Nadi Antar Kelompok

\begin{tabular}{|c|c|c|c|c|c|c|c|}
\hline Laju nadi & \multicolumn{2}{|c|}{ Fentanil } & \multicolumn{2}{|c|}{ Morfin } & \multicolumn{2}{|c|}{ Tramadol } & $\mathrm{p}$ \\
\hline Jam ke-0 & $70,00 \pm 2,796$ & $70(66-76)$ & $66,58 \pm 2,314$ & $66,5(62-70)$ & $79,75 \pm 6,240$ & $80(70-88)$ & $0,000^{ \pm *}$ \\
\hline Jam ke-6 & $74,83 \pm 4,707$ & $74(70-82)$ & $72,83 \pm 3,950$ & $72(68-80)$ & $82,00 \pm 3,191$ & $82(78-88)$ & $0,000^{\ddagger *}$ \\
\hline Jam ke-12 & $73,33 \pm 4,459$ & $73(68-82)$ & $75,00 \pm 3,861$ & $75(70-82)$ & $83,17 \pm 2,887$ & $82(80-88)$ & $0,000^{£ *}$ \\
\hline Jam ke-24 & $74,00 \pm 3,516$ & $74(66-80)$ & $74,00 \pm 4,387$ & $74(68-80)$ & $82,33 \pm 2,387$ & $83(78-86)$ & $0,000^{\mathfrak{f} *}$ \\
\hline
\end{tabular}

Keterangan : ${ }^{\ddagger}$ Kruskal Wallis; ${ }^{£}$ ANOVA 
Uji Shapiro-Wilk laju nadi pada jam ke-0, 1, 12 dan 24 pada semua kelompok didapatkan hasil normal sehingga dilakukan uji $A N O V A$. Laju nadi jam ke-0, 1, 12 dan 24 dengan uji ANOVA secara statistik berbeda bermakna, kemudian dilanjutkan uji Post Hoc. Laju nadi pada jam ke-6 tidak normal, dilanjutkan uji Kruskal-Wallis secara statistik berbeda signifikan ( $\mathrm{p}=0,000)$ dilanjutkan uji Mann-Whitney.

Tabel 16. Perbandingan Laju Nadi pada jam ke-0, 1, 12 dan 24

\begin{tabular}{llll}
\hline Laju Nadi & \multicolumn{1}{c}{ Kelompok } & MeanDifference & $\mathrm{p}$ \\
& & & $0,010^{*}$ \\
Jam ke-0 & Fentanil-Morfin & 3,417 & $0,000^{*}$ \\
Jam ke-0 & Fentanil-Tramadol & $-9,750$ & $0,000^{*}$ \\
Jam ke-0 & Morfin-Tramadol & $-13,167$ & 1,000 \\
Jam ke-1 & Fentanil-Morfin & 0,833 & $0,000^{*}$ \\
Jam ke-1 & Fentanil-Tramadol & $-11,667$ & $0,000^{*}$ \\
Jam ke-1 & Morfin-Tramadol & $-12,500$ & 0,868 \\
Jam ke-12 & Fentanil-Morfin & $-1,667$ & $0,000^{*}$ \\
Jam ke-12 & Fentanil-Tramadol & $-9,833$ & $0,000^{*}$ \\
Jam ke-12 & Morfin-Tramadol & $-8,167$ & 1,000 \\
Jam ke-24 & Fentanil-Morfin & 0,167 & $0,000^{*}$ \\
Jam ke-24 & Fentanil-Tramadol & $-8,333$ & $0,000^{*}$ \\
Jam ke-24 & Morfin-Tramadol & $-8,500$ &
\end{tabular}

Keterangan : * Signifikan

Perbedaan laju nadi kelompok fentanil-morfin berbeda signifikan ada jam ke-0, dengan laju nadi kelompok fentanil lebih tinggi daripada kelompok morfin. Perbedaan laju nadi kelompok fentanil-tramadol berbeda signifikan pada jam ke-0, 1, 12 dan 24 dengan laju nadi kelompok fentanil lebih rendah daripada kelompok morfin.Perbedaan laju nadi kelompok morfin-tramadol berbeda signifikan pada jam ke-0, 1, 12 dan 24 dengan laju nadi kelompok morfin lebih rendah daripada kelompok tramadol.

Tabel 17. Perbandingan Laju Nadi pada jam ke-6

\begin{tabular}{llll}
\hline \multicolumn{1}{c}{ Laju nadi } & \multicolumn{1}{c}{ Kelompok } & \multicolumn{1}{c}{ MeanRank } \\
\hline Jam ke-6 & Fentanil & 14,04 & 0,276 \\
Jam ke-6 & Morfin & 10,96 & \\
& Fentanil & 7,96 & $0,001^{*}$ \\
Jam ke-6 & Tramadol & 17,04 & \\
& Morfin & 6,88 & $0,000^{*}$ \\
& Tramadol & 18,13 & \\
\hline
\end{tabular}

Keterangan : * Signifikan 
Hasil uji Mann-Whitney perbandingan laju nadi kelompok fentanil -morfin pada jam ke-6 ( $\mathrm{p}=-0,276)$ tidak berbeda bermakna, antara kelompok fentanil-tramadol berbeda bermakna $(p=0,001)$ dengan laju nadi kelompok fentanil lebih rendah daripada kelompok tramadol. Antara kelompok morfintramadol berbeda bermakna $(p=0,000)$ dengan laju nadi kelompok morfin lebih rendah dari tramadol.

Tabel 18. Perbandingan Laju Napas Antar Kelompok

\begin{tabular}{|c|c|c|c|c|c|c|c|}
\hline \multirow[t]{2}{*}{ Laju napas } & \multicolumn{2}{|c|}{ Fentanil } & \multicolumn{2}{|c|}{ Morfin } & \multicolumn{2}{|c|}{ Tramadol } & \multirow[t]{2}{*}{$\mathrm{p}$} \\
\hline & Mean \pm SD & Median & Mean \pm SD & Median & Mean \pm SD & Median & \\
\hline Jam ke-0 & $10,17 \pm 0,937$ & $10(9-12)$ & $9,92 \pm 0,669$ & $10(9-11)$ & $12,08 \pm 1,165$ & $12(10-14)$ & $0,000^{* *}$ \\
\hline Jam ke-1 & $11,42 \pm 0,793$ & $11(10-13)$ & $11,17 \pm 0,718$ & $11(10-12)$ & $12,58 \pm 0,900$ & $12(12-14)$ & $0,001^{\text {** }}$ \\
\hline Jam ke-6 & $12,33 \pm 0,778$ & $12(12-14)$ & $11,08 \pm 0,669$ & $11(10-12)$ & $12,33 \pm 0,778$ & $12(12-14)$ & $0,000^{* *}$ \\
\hline Jam ke-12 & $12,50 \pm 1,000$ & $12(11-14)$ & $11,42 \pm 0,900$ & $12(10-12)$ & $12,83 \pm 1,030$ & $12(12-14)$ & $0,007^{* *}$ \\
\hline Jam ke-24 & $12,42 \pm 0,996$ & $12(11-14)$ & $11,83 \pm 0,389$ & $12(11-12)$ & $12,50 \pm 0,905$ & $12(12-14)$ & $0,097^{\star}$ \\
\hline
\end{tabular}

Keterangan : ${ }^{*}$ Kruskal Wallis, * Signifikan

Uji Shapiro-Wilk laju napas pada jam ke-0, 1, 6, 12 dan 24 pada semua kelompok didapatkan hasil tidak normal sehingga dilakukan uji Kruskal-Wallis. Laju napas jam ke-0, 1, 6, 12 dengan uji
Kruskal-Wallissecara statistik berbeda bermakna, kemudian dilanjutkan uji Mann-Whitney. Laju napas pada jam ke24 dengan uji Kruskal-Wallis secara statistiktidak berbeda signifikan.

Tabel 19. Perbandingan Laju Napas pada Jam ke-0, 1, 6 dan 12

\begin{tabular}{|c|c|c|c|}
\hline Laju Napas & Kelompok & MeanRank & $\bar{P}$ \\
\hline \multirow[t]{2}{*}{ Jam ke-0 } & Fentanil & 13,33 & 0,532 \\
\hline & Morfin & 11,67 & \\
\hline \multirow[t]{2}{*}{ Jam ke-1 } & Fentanil & 13,42 & 0,488 \\
\hline & Morfin & 11,58 & \\
\hline \multirow[t]{2}{*}{ Jam ke-6 } & Fentanil & 17,25 & $0,000^{*}$ \\
\hline & Morfin & 7,75 & \\
\hline \multirow[t]{2}{*}{ Jam ke-12 } & Fentanil & 15,46 & $0,039 *$ \\
\hline & Morfin & 9,54 & \\
\hline \multirow{2}{*}{ Jam ke-0 } & Fentanil & 7,71 & $0,000 *$ \\
\hline & Tramadol & 17,29 & \\
\hline \multirow[t]{2}{*}{ Jam ke-1 } & Fentanil & 8,54 & $0,003 *$ \\
\hline & Tramadol & 16,46 & \\
\hline \multirow{2}{*}{ Jam ke-6 } & Fentanil & 12,50 & 1,000 \\
\hline & Tramadol & 12,50 & \\
\hline \multirow[t]{2}{*}{ Jam ke-12 } & Fentanil & 11,50 & 0,428 \\
\hline & Tramadol & 13,50 & \\
\hline \multirow[t]{2}{*}{ Jam ke- 0} & Morfin & 7,13 & $0,000 *$ \\
\hline & Tramadol & 17,88 & \\
\hline \multirow[t]{2}{*}{ Jam ke-1 } & Morfin & 7,83 & $0,001 *$ \\
\hline & Tramadol & 17,17 & \\
\hline \multirow[t]{2}{*}{ Jam ke-6 } & Morfin & 7,75 & $0,000^{*}$ \\
\hline & Tramadol & 17,25 & \\
\hline \multirow[t]{2}{*}{ Jam ke-12 } & Morfin & 8,83 & $0,010 *$ \\
\hline & Tramadol & 16,17 & \\
\hline
\end{tabular}

Keterangan : * Signifikan 
Hasil uji Mann-Whitney perbandingan laju napas kelompok fentanil-morfin pada jam ke-0 $(\mathrm{p}=0,532)$ dan $1(p=0,488)$ tidak berbeda bermakna, laju napas jam ke-6 $(\mathrm{p}=0,000)$ dan 12 $(p=0,039)$ berbeda bermakna dengan laju napas kelompok morfin lebih rendah daripada kelompok fentanil. Laju napas kelompok fentanil-tramadol pada jam ke$0 \quad(p=0,000)$ dan $1 \quad(p=0,003)$ berbeda bermakna dengan laju napas kelompok fentanil lebih rendah daripada kelompok tramadol, laju napas jam ke-6 $(\mathrm{p}=1,000)$ dan $12(p=0,428)$ tidak berbeda bermakna. Laju napas kelompok morfintramadol pada jam ke-0 $(\mathrm{p}=0,000), 1$ $(\mathrm{p}=0,000), 6(\mathrm{p}=0,000)$ dan $12(\mathrm{p}=0,010)$ berbeda bermakna dengan laju napas kelompok morfin lebih rendah daripada kelompok tramadol.

\section{PEMBAHASAN}

Untuk menilai efektivitas obat, dinilai perbandingan skala nyeri antara kelompok perlakuan dengan menggunakan NRS saat diam dan bergerak. Pada jam ke-0 dan 1, tidak terdapat perbedaan bermakna skor NRS baik saat diam maupun bergerak, namun terdapat perbedaan bermakna skor NRS saat diam antara kelompok fentanilmorfin pada jam ke-6 dan 12 dengan skor NRS kelompok fentanil lebih rendah daripada kelompok morfin. Skor NRS diam kelompok fentanil lebih rendah daripada kelompok tramadol pada jam ke-6, 12 dan 24. Skor NRS saat diam kelompok morfin lebih rendah daripada kelompok tramadol pada jam ke-6, 12 dan 24. Skor NRS saat bergerak kelompok fentanil lebih rendah daripada kelompok morfin dan tramadol pada jam ke-6, 12 dan 24. Skor NRS saat bergerak kelompok morfin lebih rendah daripada kelompok tramadol ada jam ke-6, 12 dan 24. Hal ini menunjukkan efektivitas obat tertinggi secara berturut-turut: fentanil, morfin lalu tramadol.

Skor NRS saat diam maupun bergerak pada jam ke-0 dan 1 tidak terdapat perbedaan bermakna, pasien masih dalam kondisi tidak nyeri, dikarenakan kadar plasma obat analgetik yang diberikan masih tinggi dan masih terdapat pengaruh obat anestesi sebelumnya. Pada jam ke-6, 12 dan 24 mulai terdapat perbedaan bermakna skor NRS baik saat diam maupun bergerak. Pasien yang mendapat analgetik PCA fentanil atau PCA morfin lebih tidak nyeri dibandingkan yang mendapat bolus tramadol intermitten karena pemakaian PCA akan memberikan penanganan nyeri yang lebih baik karena terapi yang lebih bersifat individualistik, disesuaikan kebutuhan/permintaan pasien dan kadar opioid plasma dapat dipertahankan dengan konstan setelah MEAC tercapai. 13-15 Efektivitas PCA fentanil lebih baik daripada PCA morfin. Secara farmakologis dibandingkan morfin, fentanil lebih poten dan 160 kali lebih bersifat lipofilik sehingga mempunyai onset yang lebih cepat. Pemberian bolus fentanil (saat pasien menekan tombol permintaan dosis pada PCA ketika pasien merasa nyeri) memberikan respon analgetik yang lebih cepat daripada morfin. Pemberian PCA morfin tanpa disertai background infusion menyebabkan titrasi kadar obat tidak sepenuhnya cukup mengatasi nyeri dibandingkan PCA fentanil yang diberi backgroundinfusion, hal ini terkait 
kekhawatiran efek depresi napas dan sedasi yang mungkin timbul pada pemberian morfin kontinyu di ruangan. Dibandingkan tramadol, PCA morfin lebih efektif dikarenakan secara farmakologis morfin 10-15x lebih poten dibandingkan tramadol, melalui pemberian dengan alat PCA, pasien mendapat analgetik sesuai kebutuhannya, sedangkan dengan pemberian bolus tramadol intermitten, sebagian pasien masih nyeri, karena ambang nyeri setiap pasien dapat berbeda.

Untuk menilai kedalaman sedasi digunakan skala sedasi RASS. Terdapat perbedaan bermakna skor RASS pada jam ke-0, di mana skor RASS kelompok fentanil dan morfin lebih rendah daripada kelompok tramadol. Tidak terdapat perbedaan bermakna skor RASS antara kelompok fentanil-morfin. Secara farmakologis efek sedasi akibat fentanil dan morfin lebih tinggi daripada tramadol. Efek sedasi tersebut timbul di pada jam ke-0 setelah pemberian loadingdose, di mana kadar opioid mencapai puncaknya. Hal ini dipengaruhi pula oleh sisa efek obat anestesi umum sebelumnya.

Total dosis obat yang diberikan dalam 24 jam pertama pasca operasi MRM untuk kelompok fentanil yaitu mean 817,25 mcg dan median 811,5 (768 -888) mcg, kelompok morfin yaitu mean $14,08 \mathrm{mg}$ dan median 13,5 (10-20) mg, dan kelompok tramadol dengan mean 300 dan median (300) mg. Untuk kelompok PCA fentanyl yang mendapat backgroundinfusion $30 \quad \mathrm{mcg} / \mathrm{jam}$, sebanyak 10 pasien (83\%) masih menekan tombol permintaan dosis yang ditunjukkan dengan doseattempted dengan range 1-9 dosis. Sebanyak 2 pasien (17\%) tidak menekan tombol permintaan dosis. Hal ini menunjukkan sebagian besar pasien masih membutuhkan dosis tambahan di luar pemberian dosis kontinyu. Hal ini terkait dengan perbedaan ambang nyeri pada pasien.

Penggunaan opioid diketahui dapat mengakibatkan efek samping mual muntah, mengantuk, dizziness, pruritus, bradikardi dan hipotensi. Pada penelitian ini efek samping yang terjadi selama 24 jam pasca operasi yakni mual, muntah dan nyeri kepala. Tidak terjadi hipotensi, bradikardi, depresi napas ataupun prutitus. Mual terjadi pada kelompok fentanil sebanyak 8 pasien, morfin 8 pasien dan tramadol 7 pasien secara statistik perbedaan tidak signifikan. Muntah terjadi pada kelompok fentanil sebanyak 1 pasien, morfin 3 pasiendan tramadol tidak ada yang muntah, namun secara statistik perbedaan tidak signifikan. Opioid-Induced Nausea and Vomitting (OINV) dapat terjadi akibat stimulasi langsung reseptor $\mu$ dan $\delta$ pada chemoreceptortriggerzone (CTZ) di area postrema medula oblongata, melambatnya pengosongan isi lambung dan peningkatan sensivitas vestibular yang diduga akibat rangsang pada reseptor opioid $\mathrm{u}, \mathrm{K}$ dan $\delta$. Dizziness terjadi pada kelompok morfin 2 pasien dan tramadol 1 pasien, secara statistik perbedaan tidak signifikan.

Tingkat kepuasan pasien tertinggi pada kelompok fentanil sedangkan antara kelompok tramadol-morfin tidak berbeda bermakna. Tingkat kepuasan pasien dipengaruhi oleh rasa nyeri, rasa nyaman dan efek samping yang timbul pada 
pemberian obat. Dibandingkan kelompok PCA morfin maupun tramadol, penggunaan PCA fentanil paling efektif dalam penanganan nyeri ditandai dengan rendahnya skor NRS saat diam dan bergerak serta efek samping minimal. Penggunaan PCA morfin lebih efektif dalam mengatasi nyeri dibandingkan tramadol, namun efek samping mual muntah dan nyeri kepala yang timbul, walaupun secara statistik tidak berbeda bermakna, namun menurunkan tingkat kepuasan pasien, pasien yang mengalami mual muntah dan nyeri kepala memberi skor tingkat kepuasan yang rendah.

Tidak terjadi hipotensi (tekanan darah $<90 / 60 \mathrm{mmHg}$ ) pada setiap kelompok perlakuan selama 24 jam pasca operasi MRM. Namun terdapat perbedaan bermakna tekanan darah sistolik dan diastolik pada jam ke-0, 1 dan 12 di mana tekanan darah kelompok fentanil dan morfin lebih rendah daripada kelompok tramadol, sedangkan antara kelompok fentanil-morfin tidak berbeda signifikan. Hal ini menunjukkan fentanil dan morfin lebih menyebabkan penurunan tekanan darah dibandingkan tramadol. Secara farmakologis tramadol tidak mempengaruhi hemodinamik sedangkan fentanil dan morfin dapat menyebabkan vasodilatasi dan depresi kardiak akibat stimulasi parasimpatis, dengan efek fentanil terhadap hemodinamik lebih rendah daripada morfin.

Tidak terjadi bradikardi (laju nadi $<60 \mathrm{kali} /$ menit) pada setiap kelompok perlakuan selama 24 jam pasca operasi MRM. Namun terjadi perbedaan bermakna laju nadi kelompok morfin lebih rendah daripada fentanil pada jam ke-0. Laju nadi kelompok morfin lebih rendah daripada kelompok tramadol pada jam ke-0, 1, 6, 12 dan 24. Laju nadi kelompok fentanil lebih rendah dari kelompok tramadol pada jam ke-0, 1, 6, 12 dan 24. Hal ini sesuai kepustakaan di mana secara farmakologis efek morfin terhadap penurunan laju nadi lebih besar daripada fentanil dan tramadol. Tramadol tidak berpengaruh terhadap hemodinamik. Hal lain yang mempengaruhi laju nadi adalah rasa nyeri. Nyeri dapat meningkatkan laju nadi. Efek analgetik morfin dan fentanil lebih baik dari tramadol sehingga laju nadi pasien lebih rendah daripada kelompok tramadol. Pada penelitian ini sesuai dengan skor NRS kelompok fentanil dan morfin yang lebih rendah daripada kelompok tramadol.

Tidak terjadi depresi napas (laju napas $<8$ kali/menit) pada setiap kelompok perlakuan selama 24 jam pasca operasi MRM. Namun terjadi perbedaan bermakna laju napas kelompok morfin lebih rendah daripada kelompok fentanil pada jam ke-6 dan 12. Laju napas kelompok morfin lebih rendah daripada kelompok tramadol pada jam ke-0, 1, 6 dan 12. Laju napas kelompok fentanil lebih rendah daripada kelompok tramadol pada jam ke-0 dan 1. Efek depresi pernapasan morfin secara farmakologis lebih besar dibandingkan fentanil dan tramadol, sedangkan efek depresi pernapasan fentanil lebih besar daripada tramadol. Efek depresi napas meningkat dengan peningkatan dosis. 


\section{SIMPULAN}

Efektivitas analgetik pasca operasi MRM secara berurutan mulai dari yang terbaik: PCA fentanil, PCA morfin lalu tramadol. Tingkat kepuasan pasien tertinggi pada kelompok PCA fentanil. Perbandingan tingkat kepuasan pasien antara kelompok PCA morfin dan tramadol tidak berbeda bermakna. Penggunaan PCA fentanil dan PCA morfin aman ditandai dengan tidak terjadinya efek samping hipotensi, bradikardi ataupun depresi napas. Terjadi efek samping mual, muntah dan dizziness namun secara statistik tidak berbeda bermakna. Perbandingan efek sedasi antar kelompok tidak berbeda bermakna, kecuali pada jam ke-0 di mana skala sedasi PCA fentanil dan PCA morfin lebih dalam daripada tramadol. Tekanan darah, laju napas dan laju nadi kelompok PCA fentanil dan PCA morfin lebih rendah daripada kelompok tramadol.

\section{DAFTAR PUSTAKA}

1. Witjacksono, Villyastuti, Sutiyono D. Masalah Nyeri. In: Soenarjo, Jatmiko HD, ed. Anestesiologi. 2 ed. Semarang: Bagian Anestesiologi dan Terapi Intensif FK UNDIP; 2013:309-21

2. Carli F, Baldini G. Perioperative Pain Management and Enchanced Outcomes. In: Butterworth JF, Mackey DC, Wasnick JD, ed. Morgan \& Mikhail's Clinical Anesthesiology. Fifth ed. New York: McGraw-Hill; 2013:1102.

3. Holdcroft A, Jaggar S. Core topic in pain. New York: Cambridge University Press, 2005:188
4. Joseph A S, Kiluk J V. Breast Cancer Treatment Protocols: Localized Disease, Adjuvant Chemotherapy, HER2/neu+ Localized Disease, Adjuvant Chemotherapy, HER2/neu - Localized Disease [Internet]. Available from:http:// emedicine.medscape.com/ article/2006464-overview

5. Cheng GS, Ilfeld BM. A review of postoperative analgesia for breast cancer surgery [Internet]. Vol. 6, Pain Management. 2016. p. 603-18. Available from: http:// www.futuremedicine.com/ doi/10.2217/pmt-2015-0008

6. Hudcova J, McNicol ED, Quah CS, Lau J, Carr DB. Patient controlled opioid analgesia versus conventional opioid analgesia for postoperative pain. The Cochrane Collaboration 2012; 6: 1-11.

7. Brian $\mathrm{M}$, Winnie $\mathrm{N}$, Rodney $\mathrm{H}$, Josh G, Jeff S. The Rate and Costs Attributable to Intravenous Patient-Controlled Analgesia Errors. Hosp Pharm. 2009;44:312324.

8. Igor K. Patient-controlled Analgesia Analgesimetry and Its Problems. AnesthAnalg2009;108:1945-9.

9. Horlocker TT. Pain management in total joint arthroplasty: a historical review. Orthopedics [Internet]. 2010;33(9 Suppl):14-9. Available from: http:/www.ncbi.nlm.nih.gov/ pubmed/20839717Cheung CW et al. An audit of postoperative intravenous patient-controlledanalgesia with morphine: Evolution over the last decade. European Journal of Pain 2009;13:464 -471. 
10. Panigoro S, Hernowo BS, Purwanto H, Handojo, Haryono SJ, Arif W, et al. Panduan Penatalaksanaan KankerPayudar.Kementeri Kesehat Republik Indonesia Kom Penanggulangan Kanker Nasional [Internet]. 2008;1, 12-4, 24-6, 45.

11. Morgan GE. Pain Management.Dalam: Clinical Anesthesiology 3rded. Stanford: Appleton and Lange, 2002, 274-316.

12. San Diego Patient Safety Council. Patient controlled analgesia (PCA) guidelines of care. 2014;2014 (December):6-7. Available from: http://www.hqinstitute.org/post/ patient-controlled-analgesia-pcaguidelines-careStoneham MD, Cooper R, Quiney NF, Walters FJM. Pain following craniotomy: a preliminary study comparing PCA morphine with intramuscular codeine phosphate. Anaesthesia. 1996; 51(12): 1176-8. 